\title{
Territories of Advanced Socio-economic Development: Their Importance, Establishment Particularities and Governance Methods
}

\author{
Ludmila M. Igolkina \\ Far Eastern State Transport University, Russian Federation \\ Corresponding Email: igolkinalm@mail.ru
}

Doi:10.5901/mjss.2015.v6n6s7p328

\begin{abstract}
The article describes the problems and possible solutions to to the current state of Russia associated with the post-crisis development and economic sanctions. The emphasis is made on the Far East as one of the key areas of Russia. Specified are the constraints on the implementation of its economic potential, such as the raw material orientation of the economy, low provision of infrastructure, the remoteness of the region from the industrialized areas of the country, underdeveloped industrial and social infrastructure, weak investment opportunities, a large-scale outflow of the population, etc. The elaborated solutions include the creation of a network of special areas of advancing socio-economic development - the priority development areas (PDA), offering benefits and preferences to the companies-residents of non-extractive industries for the 70-year period. Priority development areas should act as contact zones, providing foreign economic, scientific, cultural and other forms of international cooperation with the countries of Asia-Pacific.
\end{abstract}

Keywords: Far East, priority development areas, public-private partnership, regional development

\section{Introduction}

At the present stage of development Russia is faced with many problems, largely due to post-crisis development, including an increase in the budget deficit of the country, the unfavorable change in the oil prices, the general decline of the ruble and economic sanctions. According to experts of the National Research University Higher School of Economics (HSE), assessments of medium-term prospects of national development look very unfavorably - GDP growth in 2016 is estimated at $0.3 \%$ instead of $2 \%$. The reason is that Russia has been forced to develop in an environment with a high degree of uncertainty caused by an introduction of international sanctions and tense geopolitical situation (Volkova \& Filipenok, 2015). Under the conditions of limited budget expenditures, the state is forced to look for other tools of economic development: attracting investment, creating new jobs, especially at the regional level, building on the positive foreign experience in solving similar problems (Banon, 2011; Bulletin statistique regional, 2008, 2012; Button, 2006; Global Competitiveness Report, 2012; Handler et al., 2015; Kappeler \& Nemoz, 2010; Market Update, 2012, 2013; Schoch \& den Broeder, 2013). Because in this situation these circumstances threaten the onset of the crisis in the national economy, it necessarily requires the reorientation of not only foreign but also domestic policy of the state from west to east, as well as the corresponding resource and regulatory support at the legislative level (Klimova \& Kochieva, 2015).

\section{The Economic Potential of the Far East}

Note that, although the Far East is one of the key areas of Russia, which, thanks to rich natural resource potential and geographical location is of great strategic importance, but overall it still lags behind the European part of the country in pace of economic development and implementation of the large-scale investment projects, experiencing a long-term migration outflow.

The problems hindering the realization of the economic potential of the Far East, include economic and infrastructural isolation from the rest of Russia and most of the Russian market, lower internal transport communication linkages of the territory given its vast size, low population density with focal character of the settlements, the specificity of the conditions of farming, high costs, and seasonality in delivery of goods to its northern and Arctic regions.

Wherein, the main of these problems - a large-scale outflow of people from the region lasting for many years, which is associated with low income, lack of comfortable living conditions and the general instability of the socio- 
economic situation. As a result, for the 23-year period (from 1990 to 2013) the population of the Far Eastern Federal District declined by 1.793 million people or $22 \%$. This scale of population losses is more than 7 times higher than the national average. The people of working age and of highly qualified labor represent the very significant share of the losses. Population decline is due, firstly, to migration beyond the macro-region, and secondly, a significant excess of deaths over births in recent years (Ivanter et al., 2014; Abramov, 2014; Baklanov, 2014; Leonov, 2011).

At the same time, the Far East is having the raw material export orientation characterized by low degree of diversification and innovativeness of the economy. In the early 1990s, exports of machinery, equipment and vehicles from the region accounted for more than $34 \%$. At the present time it does not exceed $3 \%$, while the proportion of raw materials, fuels, metals and raw timber is $85-90 \%$. For example, in the export structure of timber to China, the wood raw material accounts for $95 \%$, including about $70 \%$ - roundwood. At the same time in the commodity structure of the Chinese timber exports to other countries (including Japan and the US), almost $90 \%$ is paper, cardboard, building construction, furniture and other products of deep processing of raw materials (Ivanter et al., 2014).

The subjects of the Far East, there is also a significant difference between the conditions of conducting economic activity and living conditions of the population (for example, between Primorsky Territory and the Magadan region, between the Jewish Autonomous Region and the Chukotka Autonomous District), poor quality of both the social infrastructure and the quality of life and, as a consequence, the lack of comfortable living conditions in cities and towns that do not have efficient city-forming enterprises.

We believe that, on the basis of these negative factors, the federal authorities should provide assistance in the implementation of major investment projects in the Russian Far East in the following areas: 1) carrying out special (reduced) state policy in the sphere of tax, customs and tariff regulation and investment in infrastructure, 2) the creation of favorable investment climate of the Far East for both domestic and foreign investors, and 3) implementation of social policy, relevant to economic objectives.

Despite the existence of serious problems, territories of the Far East have a number of competitive advantages and capabilities that enable the evolving nature of the development policies of the eastern Russia. As already mentioned, the Far Eastern Federal District has a large area (36.08\% of the territory of Russia), huge natural resources (e.g. $80 \%$ of the reserves of diamonds, $92 \%$ tin, $33 \%$ gold, $35 \%$ silver, more than $55 \%$ of reserves of manganese, apatite ore and uranium, as well as oil, gas, timber, seafood, etc.), industrial (e.g. aircraft and ship building, defense industry, and others), export and recreational potential, large undeveloped area suitable for living and accommodation of large industrial complexes and agricultural development, favorable geographical position in general, as well as the hydropower potential of ever-increasing importance.

In addition, as already mentioned, an important advantage of the Far East of Russia is its transport and geographical location: Far East is a natural bridge of transport linkages between Europe and Asia Pacific. On the one hand, it is a land bridge, the foundation of which are the Trans-Siberian and BAM roads. Their combined capacity of more than 100 million tons of cargo per annum, and this is not the limit. On the other hand, the Far East already has the basic port infrastructure. There are twenty-nine of the sixty-six Russian sea ports, including such large ones as: Vostochny, Nakhodka, Vladivostok, Vanino. Thus, navigation in all the major ports of the Far East is a year-round. The combination of advanced port infrastructure and high-land communication in the future greatly increases the region's ability to provide transit transport services (Ivanter et al., 2014; Zausaev 2014).

It should be noted that the ratio of the major economic groth centers of the world economy is changing rapidly in favor of the Asia-Pacific Region (APR). This means that with its growing role in the global economy increases the importance of the Far East as the contact zone, providing external economic, cultural and other forms of international cooperation, especially with the countries of Northeast Asia. In these circumstances, the need to improve the state's attention to the geo-political, strategic, economic and demographic problems of the Far East increases. The most promising at the moment seems to be an innovative model of economic development of the macro-region.

Perspective development of the Far Eastern economy is heavily dependent on external factors and conditions: the regional economy in influenced not only by the changing conditions of the world economy, but also the positive changes already taking place in the Russian economy.

\section{The Model of Economic Development of the Far East}

Despite the fact, that since the 1990s to 2000s, 'Far Eastern' vector of development has undergone a marked decline, in recent years the situation in the Far East changes considerably: the legal basis for the development of both the economy of the country and its regions is formed and continues develops. Adopted is the concept of long-term socio-economic development of the Russian Federation for the period up to 2020 (approved by the. Order of the Government of the 
Russian Federation of November 17, 2008 № 1662-r), which defines the ways and the measures to ensure (for 2008 2020): a sustainable increase of the well-being of Russian citizens, the national security, the dynamic development of the economy, the strengthening of Russia's positions in the world community.

Developed and approved is the Strategy of socio-economic development of the Far East and Trans-Baikal region for the period up to 2025 (approved by the. Order of the Government of the Russian Federation of December 28, 2009 № 2094-p), which is based on projects that are of interest for both domestic and foreign investors. The basic document defining the state policy on development of the Far East, is a federal target program "Economic and social development of the Far East and the Baikal Region until 2025" (hereinafter - the Program) approved by the Government of the RF on 24.10.2013. The Program provides accelerated development, economic diversification and improvement of the sociodemographic situation in the Far East and the Baikal region.

As part of the strategic documents on socio-economic development of the country - the annual Presidential Address to the Federal Assembly (in this case the May decrees of the President of the Russian Federation), the major objectives of long-term government economic policy are defined in accordance with the development of society and the realities of the time, which include: continued diversification and modernization of the economy; the creation of new industries; development of industrial infrastructure and innovation, taking into account the evolving S\&T potential and implementation of R\&D results.

In addition, in October 2013 the Russian Ministry for the development of the Far East with the support of the Government Commission on the Socio-Economic Development of the Far East generated the development model of the macro-region, which is based on the balance between the processes of import substitution and export of finished goods (works, services) of the Far East to the countries of APR, attracting direct investments, developing small and mediumsized businesses, and, most importantly, focusing on the creation of competitive priority development areas - PDA (Brusnikinsky breakthrough: from SEZ to TASED, 2014). According to Stepanov and Orlov (2015, p.1), "such a model is developed for the Far East for the first time and should contribute to meeting the basic needs of the 'cells' in the present social system, i.e. population, government and business. However, it is assumed that it will be able to counteract a temporary domestic economic and especially the external challenges, often having political basis...". They continue by stating that "the main difference between the modern approach to the development of the Far Eastern territories is that earlier in the preparation of plans and forecasts for the development of territories and / or macro-regions, including the Soviet period, it was usually about the formation of concepts and programs for the integrated development of large socalled 'multi-site' education, including several republics, krai and regions. While today it is now based on another, rather, a 'single point' approach. It is about taking to the execution of the program of development of individual, relatively small areas adjacent to a large industrial centers, but having their own areas of specialization in the long term perspective".

\section{Territories of Advanced Socio-economic Development}

In his address to the Federal Assembly on December 12, 2013 Russian President Vladimir Putin announced the task of raising Siberia and Far East as a national priority for the entire XXI century. In the Far East and Siberia, the President proposed to "create a network of special areas of advanced economic development with special conditions for the organization of non-primary manufacturing oriented, above all, on export (Address by the President of the Russian Federation Federal to Assembly, 2013). The contents of the tasks and activities aimed at their solution are given in Table 1.

Table 1. The tasks and activities aimed at addressing the implementation of the Program

\begin{tabular}{|c|c|c|}
\hline Tasks & Activities & Remarks \\
\hline $\begin{array}{l}\text { 1. Building a network of territories of } \\
\text { advanced socio-economic } \\
\text { development (TASED) and the } \\
\text { creation of export-oriented production. }\end{array}$ & $\begin{array}{l}\text { - holding a selection of the most effective } \\
\text { projects of TASED creation; } \\
\text { - development of concepts and master plans } \\
\text { creating TASED; } \\
\text { - land survey work aimed at creating a land } \\
\text { to build TASED; } \\
\text { - creating complexes providing engineering } \\
\text { and transport infrastructure within the } \\
\text { boundaries of TASED; } \\
\text { - implementation of measures aimed at } \\
\text { creating conditions for a comfortable } \\
\text { business within the boundaries boundaries } \\
\text { of TASED; }\end{array}$ & $\begin{array}{l}\text { The state customer - Ministry for Development of Russian } \\
\text { Far East. } \\
\text { Ensuring effective implementation of the projects, creation } \\
\text { of infrastructure for TASED, as well as to perform the } \\
\text { functions of the management company of TASED via } \\
\text { specialized company with } 100 \% \text { state participation - OJSC } \\
\text { 'Dalniy Vostokt'. } \\
\text { Carry out activities to promote investment and economic } \\
\text { internationalization of the macro-region via specialized } \\
\text { company with 100\% state participation - ANO 'Agency for } \\
\text { Investment and Export Promotion of the Far East'. }\end{array}$ \\
\hline
\end{tabular}




\begin{tabular}{|c|c|c|}
\hline & $\begin{array}{l}\text { - attraction of investors to implement } \\
\text { projects within the boundaries of TASED; } \\
\text { - establishment of export-oriented industries. }\end{array}$ & \\
\hline $\begin{array}{l}\text { 2. Implementation of investment } \\
\text { projects on the principles of public- } \\
\text { private partnership aimed at socio- } \\
\text { economic development of territories }\end{array}$ & $\begin{array}{l}\text { - creating complexes providing engineering } \\
\text { and transport infrastructure; } \\
\text { - creation of production and social } \\
\text { infrastructure; }\end{array}$ & $\begin{array}{l}\text { The customer and the responsible for carrying out activities } \\
\text { - Ministry for Development of Russian Far East. }\end{array}$ \\
\hline $\begin{array}{l}\text { 3. Development of human capital in } \\
\text { order to of personnel maintenance of } \\
\text { the Programme }\end{array}$ & $\begin{array}{l}\text { - management training for the territories of } \\
\text { the macro-region; } \\
\text { - training of highly skilled workers; } \\
\text { - improving the mechanism of selection of } \\
\text { personnel in the state and municipal service; } \\
\text { - facilitate the resettlement of Russian } \\
\text { citizens and their families as to create } \\
\text { TASED and implement investment projects } \\
\text { aimed at socio-economic development of } \\
\text { territories; } \\
\text { - retraining of employees engaged in } \\
\text { TASED; } \\
\text { - establishment of APR schools; } \\
\text { - creation of a venture fund and innovation } \\
\text { infrastructure. }\end{array}$ & $\begin{array}{l}\text { The customer and the responsible for carrying out activities } \\
\text { - Ministry for Development of the Russian Far East. }\end{array}$ \\
\hline $\begin{array}{l}\text { 4. Development of transport } \\
\text { infrastructure in the macro-region to } \\
\text { provide the necessary volume of } \\
\text { freight and passenger transport }\end{array}$ & $\begin{array}{l}\text { - capital construction of new and } \\
\text { reconstruction of existing transport } \\
\text { infrastructure - road, rail, air and water. }\end{array}$ & $\begin{array}{l}\text { Government customers are: } \\
\text { Federal Road Agency; } \\
\text { Federal Agency of Air Transport; } \\
\text { Federal Agency of Maritime and River Transport; } \\
\text { Federal Railway Transport Agency. }\end{array}$ \\
\hline
\end{tabular}

Source: The federal target program "Economic and social development of the Far East and the Baikal Region until 2025" [Online] Available at: http://www.consultant.ru/law/review/fed/updprof (August 20, 2015).

Resourcing these activities to be carried out both at the expense of budget funds and extra-budgetary sources. Data on the amounts and sources of funding are presented in Table 2.

Table 2. The sources and amounts of financing of the Program

\begin{tabular}{|c|c|c|c|c|}
\hline \multirow[b]{2}{*}{ Objectives of the Programme } & \multicolumn{3}{|c|}{ Source and amount of funding for the $2015-2025$, bln. Rub. } & \multirow{2}{*}{$\begin{array}{l}\text { Total share in } \\
\text { the program, } \%\end{array}$} \\
\hline & Source of funding & $\begin{array}{l}\text { Volume of } \\
\text { funding }\end{array}$ & $\begin{array}{l}\text { Share in the source } \\
\text { structure, } \%\end{array}$ & \\
\hline \multirow{3}{*}{$\begin{array}{l}\text { Objective } 1 . \\
\text { Building a network of TASED and the creation } \\
\text { of export-oriented production. }\end{array}$} & - federal budget & 69.1 & & \multirow{3}{*}{3.9} \\
\hline & - extra-budgetary sources & 69.1 & $\begin{array}{l}51.1 \\
49.9\end{array}$ & \\
\hline & Total: & 138.3 & 100 & \\
\hline \multirow{5}{*}{$\begin{array}{l}\text { Objective } 2 \text {. } \\
\text { Implementation of investment projects on the } \\
\text { principles of public-private partnership aimed at } \\
\text { socio-economic development of territories }\end{array}$} & - federal budget; & 221.0 & & \multirow{5}{*}{83.4} \\
\hline & - consolidated budgets of subjects & 17.8 & 7.6 & \\
\hline & - extra-budgetary sources. & 2698.4 & 1.5 & \\
\hline & & & 91.8 & \\
\hline & Total: & 2937.3 & 100 & \\
\hline \multirow{5}{*}{$\begin{array}{l}\text { Objective } 3 . \\
\text { Development of human capital in order to of } \\
\text { personnel maintenance of the Programme }\end{array}$} & - federal budget; & 142.9 & & \multirow{5}{*}{10.2} \\
\hline & - consolidated budgets of subjects & 67.0 & 39.8 & \\
\hline & of the Russian Federation; & & 18.6 & \\
\hline & - extra-budgetary sources. & 149.3 & 41.6 & \\
\hline & Total: & 359.3 & 100 & \\
\hline \multirow{7}{*}{$\begin{array}{l}\text { Objective } 4 . \\
\text { Development of transport infrastructure in the } \\
\text { macro-region to provide the necessary volume } \\
\text { of freight and passenger transport }\end{array}$} & - federal budget; & 68.0 & & \multirow{6}{*}{2.5} \\
\hline & - consolidated budgets of subjects & & & \\
\hline & of the Russian Federation; & 5.3 & 77.1 & \\
\hline & - extra-budgetary sources. & & 6.1 & \\
\hline & & 14.8 & 16.8 & \\
\hline & Total: & 88.2 & 100 & \\
\hline & $\begin{array}{l}\text { Total of Program: } \\
\text { including }\end{array}$ & 3523.2 & 14.2 & 100 \\
\hline
\end{tabular}




$\begin{array}{lcc}\text { - federal budget; } & 501.2 & 2.6 \\ \text { - consolidated budgets of subjects } & & \\ \begin{array}{l}\text { of the Russian Federation; } \\ \text { - extra-budgetary sources. }\end{array} & 90.2 & 83.2 \\ & 2931.7 & \end{array}$

Source: The federal target program "Economic and social development of the Far East and the Baikal Region until 2025" [Online] Available at: http://www.consultant.ru/law/review/fed/updprof (August 20, 2015).

Analysis of Table 2 suggest, firstly, that the 'zone of responsibility' of the state in the implementation of the Programme is to create a network of TASED, the share in the funding of the implementation is $51.1 \%$ (1st objective of the program) and the development of transport infrastructure in the macro-region, the share of financing in the implementation of the program amounts to $77.1 \%$ (4th objective of the program), and secondly, the largest share $(83.4 \%$ ) in financing the implementation of the program is for investment projects carried out on the basis of the principles of public-private partnerships; thirdly, in the total sources of funding for $83.2 \%$ are non-budgetary sources; $14.2 \%$ - financing from the budget of the Russian Federation; $2.6 \%$ - in the consolidated budgets of the consolidated budgets of subjects of the Russian Federation.

It should be noted that during the discussion of the idea of creating TASED, there were different points of view, including the opposite. Thus, some believe the creation of the TASED is an ineffective project of the government, justifying it by the fact that TASED and existing SEZs are almost identical, as their operation is aimed at the development of certain sectors of the business and attract investors.

As an example, a fragment of speech of the Secretary of the Public Chamber of Russia Alexander Brechalova who criticized preparing a draft law on priority development areas (PDA) in the Far East: "Entrepreneurs from the Far East are afraid that the priority development areas (PDA) in the form proposed now is another 'zilch', which does not entail the accelerated development of the region, since it does not take into account the interests of small and medium-sized enterprises" (Brechalov criticized the bill on the development of the Far East, 2014). It was noted that it was not his opinion, but "the position of the professional community and businessmen. People do not have the feeling that the territories of advanced socio-economic development will be the real driver".

Others, by contrast, believe that in TASED or PDA have a great future and that their creation will 'push' the development of the regions accelerating development of the country, will increase the production capacity, the efficiency of use of available resources, changing the raw material orientation of the economy.

We believe that the creation of TASED in the Far East and other measures for the formation of the special conditions should be evaluated not as a loss for the national budget but a mechanism to increase the economic stability of the macro-region, acting as a linkage point, provided the activated role of Russia at the Asia-Pacific region.

At the end of 2014 in order to create a sustainable system of attracting investments and implementation of investment projects, improvement of living standards and the pace of socio-economic development was enacted the Federal Law № 473-FZ of 12.29.2014 "On the territories of advanced socio-economic development the Russian Federation" (hereinafter - Federal law), which entered into force on 30 March 2015. Territories of advanced socioeconomic development are the territories of the Russian Federation, including the closed cities, which established a special legal status of the business and other activities in order to create favorable conditions for attracting investments, ensuring rapid socio-economic development and the creation of favorable conditions for the life of the population. Infrastructure of the TASED will include land, objects of transport, energy, utilities, engineering, social, innovation, and others being within or outside its territory, but ensuring its functioning (Article 2 of the Federal Law № 473-FZ dated 29.12.2014). According to the decision of the Russian Government, the TASED are created for a period of 70 years, which if necessary can be extended (Article 3 of the Federal Law № 473-FZ of 29.12.2014).

\section{Creation, Management and Operation of the Priority Development Areas}

We shall consider in more detail issues related to the peculiarities of the creation, management and operation (tax issues) of the TASED.

In accordance with Federal Law № 473-FZ, the following conditions for creating TASED are provided:

1) they are created by the decision of the Government of the Russian Federation (par. 1 of Art. 3);

2) they are established in the territory of the municipality or in the territories of several municipalities within a single subject of the Russian Federation (Art. 4);

3) they cannot be created within the borders of a special economic zone or area of territorial development. The structure TASED cannot enter the special economic zone or area of territorial development (par. 8, Art. 3); 
4) within three years from the date of entry into force of the Federal Law № 473-FZ TASED will be created on the territories of the Russian Federation, members of the Far Eastern Federal District, and after three years - in the other subjects of the Russian Federation (Art. 35).

Here are the steps of obtaining a resident status of TASED by a legal entity or individual entrepreneur in accordance with the Federal Law № 473-FZ dated 29.12.2014:

1. Application for conclusion of an agreement on the implementation of activities in the management company of TASED submitted by a legal entity or individual entrepreneur.

2. Consideration of the application within 15 working days.

3. Adoption of decisions by the Management Company of the possibility of / refusal to sign the agreement on the implementation of activities.

4. Conclusion of an agreement on the implementation of activities within the boundaries of TASED, resident status and entry in the register of residents of TASED obtaining by a legal entity or individual entrepreneur.

Management of TASED will be carried out through a specially organized systems' actions aimed at ensuring sustainable and balanced reproduction of social, economic, natural, innovative potentials of the territory, while maintaining the positive dynamics of the parameters of the level and quality of life (Popov, 2015, Katunina, 2010). In accordance with the Federal Law № 473-FZ (art. 6, 7, 8), implementation of such actions will be done by supervisory board, authorized federal agency and management company. The management system of TASED has two subsystems: controlling and controlled. The subjects of control are; the supervisory board in the person of representatives of the authorized federal body, the supreme executive body of state power of subjects of the Russian Federation; other state bodies and executive body of the municipality, the management company, organization of regional unions (associations) of trade union organizations and territorial associations of employers with the right to participate in matters on the share of foreign workers involved by a TASED resident. Control object is the federal executive body authorized by the Government of the Russian Federation in creating TASED on the territory of the Federal District as well as the management company represented by the Company and (or) affiliated economic society, which would act as a developer of TASED infrastructure, ensure its functioning, keep a register of residents and, in addition, provide state and municipal services in 'one-stop shop' manner and organize the provision of resident services required for the implementation of their activities. The control objects also include socio-economic processes, district, regions, and municipalities.

It seems that, along with issues such as building a coherent system of socio-economic development of the Far East, coordinating the activities of public authorities and their collaboration, must be enabled the issues related to the development of cooperation with private investors and public organizations.

In reference to the decree of the Government of the Russian Federation it is stated that the activities of the Corporation for the development of the Far East will be financed through the budget allocations in the state program "Socio-economic development of the Far East and the Baikal region". Note that the total funding of the program is 346 billion rubles, of them 73 billion are allocated in 2015, 77 billion in in 2016.

The interaction of subjects and objects by means of the control actions and feedback will enable the purposeful management of the TASED activities. Management of collaboration of fixed in laws, presented in plans, programs, guidelines, etc. Feedback are the results of direct observation and control on behalf of the subject of management, statistical and other reports.

It should be noted that, in addition to creating TASED, the Ministry of Economic Development is considering other options for accelerated development of certain areas of the Far East. So, in 2014, a decree was signed by Government of 18.08.2014 № 822 "On creation in the city of Vladivostok a special economic zone (SEZ) of industrial type" that will be created on the basis of car factory 'Sollers'. According to the analytical agency AUTOSTAT, for the construction of a special economic zone 'Sollers' in the Primorye Territory the federal and regional budgets provided more than 5 billion rubles and 300 million rubles respectively. Private investment in the SEZ project 'Sollers' will amount to 10 billion rubles (Autostat, 2015).

In addition, in October 2015 it enters into force the Federal Law of the Russian Federation of July 13, 2015 № 212FZ "On the free port of Vladivostok", which will operate a special preferential legal and tax regime for business and investors, free customs zone and visa-free visits. The state will give residents a free road and engineering infrastructure. Residents of Freeport enjoy preferences and privileges on income tax: in the first five years a reduced rate is applied - no more than $5 \%$ over the next five years - not less than $10 \%$.

In February 2015, the so-called first 'short list' TASED is approved, determining the first three PDA in the Far Eastern Federal District. So, the TASED 'Khabarovsk' is located in a suburb of the city of Khabarovsk, where it is planned to establish production of thermal insulation materials, trubo-rabbet, develop metallurgy, building logistics centers, greenhouses and others. TASED 'Komsomolsk' focuses on production of components for the aviation industry. Specialty 
of TASED 'Nadezhdinskaya' (Primorsky Krai), which is organized in the suburbs of Vladivostok, is on production and logistics centers associated with the ports (Larina, 2015).

In the new system of TASED, the special conditions for entrepreneurship and other activities are defined, where the residents of TASED will be individual entrepreneurs or legal persons from commercial organizations, state registration of which will be based in TASED, according to the legislation of the Russian Federation - with the exception of public and municipal unitary enterprises - (Federal Law № 479-FZ) and based on the Agreement on the implementation of activities in the TASED.

According to the Federal Law № 380-FZ, № 519- FZ and № 473-FZ, the TASED will enjoy a special legal regime of doing business, which includes: 1) the establishment of preferential tax rates (Table 3); 2) the establishment of preferential rental rates for the use of immovable property; 3 ) deregulation in both the public (supervision) and municipal control; 4) prioritize connecting to infrastructure, the construction of which will be funded from the federal budget; 5) in the application of the customs procedure of free customs zone (upon decision of the Government of the Russian Federation); 7) the establishment of lower tariffs on insurance premiums (Table 4); 8) the possibility of acceleration and simplified version to recruit skilled foreign staff.

Comparative characteristics of the size of the standard rates of taxes and tax rates for residents TASED is presented in Table 3.

Table 3. Comparative characteristics of the size of the standard rates of taxes and tax rates for residents TASED

\begin{tabular}{|c|c|c|}
\hline Type of tax & $\begin{array}{l}\text { Tax rate for TASED } \\
\text { residents }\end{array}$ & Standard tax rate \\
\hline Corporate income tax (federal tax) & $0 \%$ & $\begin{array}{l}\text { Basic rate }-20 \% \\
\text { inclusing } \\
-2 \% \text { the tax rate to the federal budget; } \\
-18 \% \text { the tax rate to the regional budget }\end{array}$ \\
\hline $\begin{array}{l}\text { The tax on mineral extraction (using a discount factor } \\
\text { that characterizes the territory of mining, which is } \\
\text { assumed to be equal) }\end{array}$ & $\begin{array}{l}\text { Decreasing } \\
\text { coefficient: } \\
0 \text { - first } 2 \text { years } \\
0.2-3-4 \text {-th year } \\
0.4-5-6 \text {-th year } \\
0.6-7-8 \text {-th year } \\
0.8 \text { - 9-10-th year } \\
1.0 \text { - from 11-th year }\end{array}$ & In accordance with the Tax Code chapter 26 \\
\hline VAT & $\begin{array}{l}0 \% \text { (right to full } \\
\text { compensation) }\end{array}$ & $18 \%$ \\
\hline Property tax & $\begin{array}{l}0.5 \% \text { - first } 5 \text { years; } \\
1.1 \% \text { - following } 5 \\
\text { years }\end{array}$ & $\begin{array}{l}\text { 2.2\% (art. } 380 \text { Tax Code), unless otherwise provided by the } \\
\text { laws of the Russian Federation }\end{array}$ \\
\hline Land tax & $0 \%$ & $\begin{array}{l}\text { Land tax is established, put into effect and terminates in } \\
\text { accordance with the Tax Code and the regulations of the } \\
\text { municipalities an average of 1.5\% } \\
\text { (Art. } 394 \text { section X of Part } 2 \text { of the Tax Code (as amended in } \\
\text { the Federal Law of 29.11.2014 № 382-FZ) }\end{array}$ \\
\hline
\end{tabular}

Source: Federal Law № 473-FZ of 29.12.2014, P.2 tax code of RF

Another resident preferences for TASED are reduced rates for insurance premiums payable to the Pension Fund, Social Insurance Fund, and the Federal Compulsory Medical Insurance Fund (Table 4).

Table 4. Comparative characteristics of payment of insurance premiums for non-residents and TASED residents

\begin{tabular}{lcc}
\hline Fund & Standard tariff, \% & Tariffs of TASED residents, \% \\
\hline Pension Fund & 22 & 6.0 \\
Social Insurance Fund & 2.9 & 1.5 \\
Federal Compulsory Medical Insurance Fund & 5.1 & 0.1 \\
Total & 30 & 7.6 \\
\hline
\end{tabular}

Source: Federal Law of 24.07.2009 №212-FZ "On the insurance premiums to the Pension Fund of the Russian Federation, the Social Insurance Fund of the Russian Federation, the Federal Compulsory Medical Insurance Fund" Article 58.2. Rates of insurance premiums in 2012 - 2017. [Online] Available at: http://www.consultant.ru/document/cons_ doc_LAW_89925/27fd7ce79febc512c5e1b8b8e5624826c5e5a506 (August 16, 2015); Federal Law № 473-FZ of December 29, 2014. 


\section{Conclusion}

The increase in the budget deficit of the country, adverse changes in oil prices, depreciation of the ruble and economic sanctions necessitate a reorientation of foreign and domestic policy of the state from west to east. As the center of business and economic activity increasingly shift to the countries of Southeast Asia, China, the Far East investors have additional benefits for business development in these areas.

Development of the Far East on the basis of its rich natural resources should be understood as a common basis. At the moment, the most promising seems innovative model of economic development of the region. This model assumes diversification of the economy with a focus on human capital development, and the need to stimulate the emergence of new activities, preventing further degradation of the region.

The key role should be given to the formation of areas of advanced socio-economic development (i.e. priority development areas, PDA) over the 70-years period, established under the terms of benefits and preferences provided to their residents. Thus, creating a unique opportunity for accelerated social and economic development, as well as attracting additional investment to the Far East.

\section{References}

Abramov, A.L. (2014), Towards the concept of a territory of advanced socio-economic development in the Primorsky Territory. Rostovon-Don: Far Eastern Federal University.

Address by the President of the Russian Federation Federal to Assembly (2013), [Online] Available at: http://kremlin.ru/events/ president/news/19825. (August 08, 2015).

Autostat (2015), Investors will invest 10 billion rubles in the development of the SEZ 'Sollers' in Primorye. [Online] Available at: http://www.autostat.ru/news/view/20481/. (May 05, 2015).

Baklanov, P.Ya. (2014), Priority development areas: concept, structure, approaches to identification. Regional research, 3 (45), 12-19.

Banon, J.-C. (2011), Partenariat public-privé et croissance en Europe. Confrontations Europe, 95, 28.

Brechalov criticized the bill on the development of the Far East (2014). Vzdlyad. [Online] Available at: http://vz.ru/news/2014/10/10/ 709902.html. (August 10, 2015).

Brusnikinsky breakthrough: from SEZ to TASED (2014), Pacific Star. [Online] Available at: http://toz.khv.ru/newspaper/bez_rubriki/ brusnikinskiy_proryv_ot_oez_do_toserl. (September 08, 2015).

Bulletin statistique regional (2008), Institut de la statistique du Qu^ebec. [Online] Available at: http://www.stat.gouv.qc.ca/regions/profils/ bulletins/bull_regions_pdf.htm (October 23, 2015).

Bulletin statistique regional (2012), Institut de la statistique du Quéebec. [Online] Available at: http://www.stat.gouv.qc.ca/regions/ profils/bulletins/bull_regions.htm (October 23, 2015).

Button, M. (2006), A Practical Guide to PPP in Europe. UK: Working, City \& Financial Publishing.

Global Competitiveness Report 2012-2013 (2012). Geneva: World Economic Forum.

Handler, H., Koebel, B., Reiss, Ph., \& Schratzenstaller, M. (2015), The size and performance of public sector activities in Europe. [Online] Available at: http://129.3.20.41/eps/pe/papers/0507/0507011.pdf (October 12, 2015).

Ivanter, B., Kozhemyako, O., \& Kuvalin, D. (2014), Long-term socio-economic development of the Far East and Trans-Baikal: the main problems and challenges. Network edition of the Center for Research and analytics at the Fund of historical perspective. [Online] Available at: http://www.perspektivy.info/rus/ekob/dolgosrochnoje_socialno-ekonomicheskoje_razvitije_dalnego_vostoka_i_ zabajkalja_osnovnyje_problemy_i_zadachi_2014-02-28.htm. (August 11, 2015).

Kappeler, A., \& Nemoz, M. (2010), Public-Private Partnerships in Europe - before and during the recent financial crisis. Economic and Financial. Luxembourg: EIB.

Katunina, I.V. (2010), Managerial competence in the context of organizational development: content and structure. Kadrovik. HR management, 3(1), 5-13.

Klimova, N.V., \& Kochieva, Yu.S. (2015), The development of the Far Eastern Federal District as a national priority of economic growth of the XXI century. Scientific journal of KubGAU, 105(01), 1-15.

Larina, L. (2015), The first three territories of advanced socio-economic development (TASED) took to the start. Far Eastern capital, March. [Online] Available at: http://dvkapital.ru/timezone/dfo_18.03.2015_6889_pervye-tri-territorii-operezhajuschego-sotsialnoekonomicheskogo-razvitija-toser-vyshli-na-start.html?printr. (Aügust 17, 2015).

Leonov, S.N. (2011), Analysis of the conditions of strategic development of the Russian Far East after the crisis. Bulletin of Pacific State University, 1(20), 159-168.

Market Update (2012), Review of the European PPP Market in 2012. [Online] Available at: http://www.eib.org/epec/resources/ Market\%20Update\%202012.pdf (October 7, 2015).

Market Update (2013), Review of the European PPP Market in 2013. [Online] Available at: http://www.eib.org/epec/resources/ publications/epec_market_update_2013_en.pdf (October 7, 2015).

Popova, O.A. (2015), Features of organization and management of the territory of advancing social and economic development. Bulletin of the Buryat State University, 2(2), 102-105. 
Schoch, M., \& den Broeder C. (2013), Linking information on policy effectiveness and efficiency to budget decisions in the Netherlands. OECD Journal on Budgeting, 3, 1-5.

Stepanov, K.I., \& Orlov, S.L. (2015), A new paradigm in the national control system: formation of territories of priority development in the Far Eastern Federal District. Problems of modern economics, 1(53), 203-204.

Volkova, O., \& Filipenok, A. (2015), GDP under reconsideration. RBC business daily. [Online] Available at: http://www.rbcdaily.ru/ economy/562949996468808. (August 8, 2015).

Zausaev, V.K. (2014), Russian Far East: answers to new challenges. Analytical Bulletin on socio-economic development of the Far East and the Baikal region for the long term, 8 (526), 7-20. 